\title{
RECONCILIATION IN ZIMBABWE: THE CONFLICT BETWEEN A STATE-CENTRED AND PEOPLE- CENTRED APPROACH
}

\section{Ruth Murambadoro and Cori Wielenga ${ }^{1)}$ Department of Political Sciences University of Pretoria, South Africa}

\section{Abstract}

Reconciliation has become an integral part of the post-conflict peacebuilding process, and has come to be seen as an integral part of sustaining peace and security, particularly at the local level. The tension between a state security and human security approach to peacebuilding is particularly evident in national reconciliation and transitional justice processes. There is a continued emphasis on high-level reconciliation processes and the reconciliation of elite actors over processes that facilitate reconciliation at the community level. This article explores this in the case of Zimbabwe, where the emphasis is on a state-based approach to resolving conflict, which fails to take into account or address the needs and issues that affect local communities. Drawing from fieldwork undertaken in Matabeleland in April, 2014, this article describes what community members identify as their central needs when it comes to reconciliation, within the context of the state-driven processes that have been implemented to date.

\section{Introduction}

Zimbabwe has a long history of violent conflict spreading over decades, including the independence struggle from 1965-1979, the Gukurahundi massacres from 1980-1987, and the post-2000 electoral violence, which entrenched divisions in various communities around the country (Du Plessis and Ford 2009, Sachikonye 2011a). The government has 
implemented several high-level initiatives with the intention of resolving the conflict between political elites. This has included the Lancaster House Agreement in 1979, the Dumbutshena and Chihambakwe Commissions of Inquiry in 1981 and 1983, the Unity Accord in 1987, and the Global Political Agreement (GPA) in 2008. Yet all of these processes have remained largely at a political and elite level, with little impact on local communities.

There has been an attempt to introduce government institutions that will facilitate reconciliation on the local level through, for example, the establishment of the Organ for National Healing, Reconciliation and Integration (ONHRI) in 2009 (CCJPZ 1997, Machakanja 2010). ONHRI was dissolved in 2013, though, and is set to be replaced by the National Peace and Reconciliation Commission (NPRC) as guided by the new Constitution which was adopted by parliament in February 2013.

Peacebuilding and conflict resolution processes across the continent have been widely criticised for their elite-focus, lack of local legitimacy, lack of broad, local participation, and insensitivity to local needs (Sriram 2007; Taylor 2007). The discussion in this article contributes to this growing critique by drawing from the experiences of local communities in Matabeleland, Zimbabwe. Matabeleland was chosen for this discussion because of the particular effect of Gukurahundi, otherwise known as the Matabeleland massacres, which took place in the 1980s and have not been acknowledged or dealt with to date. Fieldwork that was undertaken in Matabeleland in April, 2014 ${ }^{2}$ ) reveals that the high level political processes in Zimbabwe have had very little resonance with the needs and issues of these communities.

Our particular interest within the peacebuilding debate is in reconciliation. We follow the definition of Karen Brounéus (2003: 20), namely, that reconciliation is "a societal process that involves the mutual acknowledgement of past sufferings and the changing of destructive attitudes and behaviour into constructive relationships towards sustainable peace". Our central argument is that the fact that Gukurahundi has not been acknowledged will hamper any possible reconciliation process in Zimbabwe. We also draw from John Lederach's (1997: 28) four-part model of reconciliation, which includes peace, truth, justice and mercy (this last sometimes being interpreted as 'forgiveness' or 'healing'). Although the relationship between these remains complex and insufficient, research has been undertaken to understand the relationship between them (Brounéus 2009), these were nevertheless themes that 
arose from community members in discussions around reconciliation.

This article thus explores the tension between a state-security and human-security approach in the context of Zimbabwe, with a particular focus on reconciliation. It describes the various ways in which the government and international community have attempted to resolve the conflict in Zimbabwe. It then draws from the fieldwork that was undertaken in Matabeleland, including interviews with community members in the Nkayi District, and interviews with civil society leaders and government officials in Bulawayo and Harare, to explore what local communities identified as their primary needs and issues related to reconciliation. The Nkayi District in the Matabeleland North Province ${ }^{3)}$ of Zimbabwe was chosen for the research because it stands at the intersection of the conflicts that have occurred in the country over the past three decades.

\section{Resolving conflict in Zimbabwe at the national level}

Zimbabwe has seen a range of high level processes that have had the intention of resolving episodes of violent conflict. In many cases, the approach to ensuring peace has been through offering blanket amnesties for gross human rights violations (CCJPZ 1997, Eppel 2006, Sachikonye 2011b). Several scholars argue that the government has intentionally paid little attention to addressing past injustices in order to avoid being implicated themselves (Du Plessis and Ford 2009). Protecting the country's territorial integrity and sovereignty has been more important than holding perpetrators to account (Raftopoulos and Savage 2004). As described by De Waal (1990) and Mashingaidze (2010), the government has repeatedly ignored the demands by survivors of the Matabeleland massacres (1980-1987), the post-2000 electoral violence, land invasions (2000-2001) and Operation Murambatsvina ${ }^{4}$ (2005), where amnesty provisions were offered to the perpetrators but little or no public acknowledgement was given to the victims with regard to the suffering experienced.

Zimbabwe has a long history of being ruled as a one-party state. As De Waal (1990) observes, both the pre-independence regime (under lan Smith) and post-independence regime (under Robert Mugabe) have been embroiled in political conflict aimed at destroying legitimate 
alternative political parties. Sachikonye (2011) adds that the current political rivalry between the ruling and opposition parties is an extension of the historical pattern of intolerance for political opposition that began during the colonial era. Over 30000 civilians died and many other human rights violations occurred in the national struggle for independence (1965-1979) between the Rhodesian Front (RF) and the liberation movements (the Zimbabwe African National Union Patriotic Front [ZANU-PF] and the Zimbabwe African People's Union [ZAPU]) (Ranger 2010, Zambara 2012).

Political rivalry has continued after the country gained independence in 1980, as evident in the conflict between ZANU-PF and ZAPU (1980-1987), and ZANU-PF and the two formations of the Movement for Democratic Change (MDC) since 1999. The political leadership ruling the country has emphasised elite-level reconciliation through the signing of agreements with its rival parties. Ndlovu-Gatsheni (2009) points out that the 1979 Lancaster House Agreement led to the formation of a coalition government made up of the minority Rhodesian Front (RF) Party, ZAPU and ZANU-PF, but the commitment of the new government to building a united nation failed to materialise. He asserts that the new government failed to set up a framework that allowed victims to solicit justice or compensation, as well as the necessary institutions to offer psychosocial support to the communities that encountered violence.

Although the then Prime Minister Robert Mugabe did allude to the need for forgiveness through his speech on the evening of his first inauguration on 17 April 1980 in which he proclaimed that, "the wrongs of the past must now stand forgiven and forgotten" (CCJPZ 1997). But the emphasis has consistently been on 'forgetting' rather than dealing with the past. The possibility for building a united nation in line with Mugabe's proclamation that, ".... oppression and racism are iniquities that must never again find scope in our political and social system", was disrupted in 1982 with the outbreak of a conflict between ZANU-PF and ZAPU officials, which led to the Matabeleland massacres or Gukurahundi (Zhira 2004).

Gukurahundi is a Shona term that refers to "the first rain that washes away chaff before spring" (CCJPZ 1997). In the case of the Gukurahundi massacres, the term has been used to refer to the killings and torture of over 20000 people and the displacement of thousands of others in the Midlands and Matabeleland area in Zimbabwe in the 
early 1980s. It was carried out by the government sanctioned security forces (the Fifth Brigade and Police Intelligence) in the Midlands and Matabeleland regions of Zimbabwe between 1981 and 1987, during a government campaign to destroy the stronghold of the Zimbabwe People's Revolutionary Army (ZIPRA) ex-combatants in these regions (Msindo 2012, Vambe 2012). The Fifth Brigade was a special task force (mainly comprised of Shona people and the Zimbabwe African National Liberation Army [ZANLA] ex-combatants) which had been trained by North Korean forces to settle the rivalry between the government (ZANU-PF) and ZIPRA ex-combatants (the armed wing of ZAPU) who were largely comprised of the Ndebele ethnic group (CCJPZ 1997).

The Unity Accord, signed between ZANU-PF (represented by Robert Mugabe) and ZAPU (represented by Joshua Nkomo) on 22 December 1987 halted the Gukurahundi massacres and merged ZANU-PF and ZAPU into one party taking the name ZANU-PF under the leadership of Robert Mugabe. This day is now commemorated as a national public holiday. No efforts have been made by the government to address the social injustices that occurred during the Gukurahundi era. Instead, the government issued an amnesty proclamation pardoning all crimes committed (CCJPZ 1997, Ndlovu and Dube 2013). Many scholars have questioned the commemoration of 22 December (Unity Day) as the day seems to symbolise the silence of the government in terms of dealing with the past (Mashingaidze 2010; Msindo 2012; Ndlovu-Gatsheni 2009). The only acknowledgement by the government in relation to Gukurahundi was the proclamation by President Mugabe that the incident was a 'moment of madness' during the funeral of the late vice president Joshua Nkomo, a father figure of the Ndebele population (Mashingaidze 2010). As will be discussed later in the article, this proclamation has raised many debates among the Matabeleland community, with many challenging the government to take responsibility for their actions (Ndlovu-Gatsheni 2012).

While the violence in Matabeleland was taking place, the Dumbutshena and Chihambakwe Commissions of Inquiry in 1981 and 1983 were implemented (CCJPZ 1997 Machakanja 2010, Machinga 2012). According to CCJPZ (1997) the Dumbutshena Commission of Inquiry was set up to investigate the violence that occurred at Entumbane in Bulawayo and other demobilisation camps across the country following the 1981 clashes between ZANLA and ZIPRA ex-combatants. The Chi- 
hambakwe Commission of Inquiry was established to investigate the Gukurahundi massacres in the Midlands and Matabeleland regions. Findings of both commissions were submitted to the government but the contents of the reports on the investigations have never been made public. Until today, human rights activists in the country, for example, the Zimbabwe Victims of Organised Violence Trust (ZIVOVT) and Ibhetshu LikaZulu, have been asking the government to release the findings without any success (CCJPZ 1997, Ndou 2012).

Between Gukurahundi and the political violence that began in 2000, no further attempts were made to deal with the violence of the past. The GPA signed in September 2008 was intended to bring to an end the political violence that has been rampant throughout Zimbabwe since 2000. The GPA was the result of a mediation process initiated by the Southern African Development Community (SADC) and the African Union (AU) led by former president of South Africa, Thabo Mbeki (Sibanda 2011, Du Plessis and Ford 2009). It resulted in a transitional Inclusive Government (IG) comprised of ZANU-PF, led by Mugabe, and the two MDC formations, namely, MDC-T, led by the then Prime Minister Morgan Tsvangirai, and MDC-M led by Arthur Mutambara, who was later replaced by Welshman Ncube (Mashingaidze 2010).

Article VII of the 2008 GPA was titled "equality, national healing, cohesion and unity" and significantly included agreements that would contribute to a culture of human rights. However, this article does not explicitly make use of the terms 'reconciliation' or 'justice', and as Machakanja (2010: 5) argues, "Article VII was designed to respond to socio-political issues at a macro or national level and to resolve national political challenges with a view to restoring social cohesion and national unity. It is the needs of the nation, not individuals that are of paramount concern in this Article". This article did stipulate the need for the IG to create a framework for the country to formally recognise the social injustices of the past and promote respect for human rights, which culminated in the establishment of ONHRI in 2009 (Machakanja 2010).

ONHRI has been critiqued by several scholars primarily because it had a top down approach that failed to cater for the demands of local communities (Machakanja 2010, Mbire 2011). ONHRI was also critiqued for being poorly structured and having a confused mandate that made it difficult for the parties involved to set up applicable guidelines for addressing the past. Part of ONHRI's confusion was caused by the unwillingness of some members of the government, in particular ZANU- 
PF representatives, to acknowledge responsibility for past incidents, such as the Matabeleland massacres (1980-1987), and the difficulty in determining the parties to be reconciled (Machinga 2012, Mashingaidze 2010). Where some emphasised the reconciliation of members of political parties (ZANU-PF and MDC), others felt the reconciliation of divided ethnic groups needed to be included.

Mashingaidze (2010) adds that ONHRI might have failed because, although it was expected to run as an independent body, the authority of the organ to exercise its mandate remained in the hands of the ruling government. Machakanja (2010) maintains that conflict of interests among parties could not be resolved because the ruling party ZANU-PF has been implicated in many of the incidents of violence that ONHRI was supposed to address. On several occasions, the meetings of ONHRI were sabotaged by members of the ruling party, ZANU-PF (Hapanyengwi-Chemhuru 2013). For example, in May 2010 nearly 500 ZANU-PF supporters disrupted a meeting conducted by the ONHRI in full view of the late Vice President, John Nkomo (co-chair of ONHRI). Significantly, the co-chair of ONHRI, Mzila-Ndlovu (MDC-N) was detained in April 2011 for pointing out at a meeting in Lupane that the government needed to compensate victims of the Gukurahundi massacres (Sachikonye 2011b). Government security forces allegedly feared that the comments made by Mzila-Nkomo would incite the community to violence. Thomson and Jazdowska (2012) add that because of the above challenges the leadership of ONHRI, particularly opposition parties, were reluctant to continue bringing these kinds of contentious issues up in the interest of maintaining favourable relations in the IG. Thus, in the interest of preserving the power-sharing agreement, it appears opposition parties calculated that the coalition would mostlikely collapse if the demands for acknowledgement of past violence continued. The mandate of ONHRI ended when the IG was dissolved in 2013 and little progress was made by the organ to address the past and to promote reconciliation in the country (Sokwanele 2013).

Most recently, through the process of developing Zimbabwe's amended Constitution, another attempt has been made to initiate a national reconciliation process (Sokwanele 2013). Chapter 12 of the 2012 amended Constitution of Zimbabwe prescribes that the government should set up independent commissions that promote democracy in the country; they are the Zimbabwe Anti-Corruption Commission (ZACC), Zimbabwe Electoral Commission (ZEC), Zimbabwe Human 
Rights Commission (ZHRC), Zimbabwe Gender Commission, Zimbabwe Media Commission and the National Peace and Reconciliation Commission (NPRC).

Zimbabwe Human Rights NGO Forum (2013) argues that the effectiveness of the above commissions and their ability to work independently remains questionable. The forum points out that given the monolithic political architecture of the government of Zimbabwe, it is unlikely that the provisions in Section 235 of the new Constitution (which postulates the independence of commissions) can be satisfied by the current ruling government. Though Section 235 stipulates that the above commissions are independent and not subject to control by any external actors (including political actors), they remain accountable to the parliament (Sokwanele 2013, Zimbabwe Human Rights NGO Forum 2013).

As noted by Sokwanele (2013), the NPRC, which is still under construction, will succeed ONHRI and is intended to carry forward the work that began with ONHRI for the next ten years. However, criticisms against the NPRC are already surfacing in the media and amongst civil society organisations, on the grounds of the method of appointment of commissioners, enabling subsidiary legislation, the absence of an enabling environment and accountability to meet the demands of the citizens who require results from the commission, among others (Zimbabwe Human Rights NGO Forum 2013). Sokwanele (2013) argues that the appointment of commissioners by the president potentially weakens the legitimacy and transparency of the process, because, given the history of the executive's decision-making process, the appointed commissioners are most likely to be supporters of the president, which makes it difficult to distinguish the office of the president from the commission. Zimbabwe Human Rights NGO Forum (2013) points out that it becomes a mere cosmetic exercise if the commission does not get a budget from the government to support its staff and resources to reach out to local communities. Langa (2014a) argues that the commission is also likely to fail if it is not supported by an enabling legislation to legitimise the process. Zimbabwe Human Rights NGO Forum (2013) maintains that the NPRC is likely to become another form of political convenience and an ornamental reconciliation project for the country. 


\section{Resolving conflict in Zimbabwe at the international level}

Civil society organisations ${ }^{5)}$ (CSOs) dealing with the Zimbabwean national crisis have increased over the past decade to fill the gap created by the inaction of the government. Through their outcry on various media platforms about the incidents of violence in Zimbabwe, they have attracted the attention of global actors to the conflict. The United States (US), Australia and Britain have responded to the conflict by, amongst other things, imposing targeted sanctions on the government. An example of this is the European Union (EU) banning of travel privileges of ZANU-PF government officials and the economic sanctions since 2002 (International Crisis Group 2008). The restrictions prohibited specified local businesses from trading with many European countries and subsequently weakened the country's economy. Ndlovu-Gatsheni (2013) and Sachikonye (2011b) argue that the restrictions levelled at the government have led the ruling party to focus on combating the regime change efforts of European countries and to oppose any reconciliation processes in the country that threaten its credentials and power base.

China and other Asian countries, such as North Korea and Malaysia, have mostly supported the government of Zimbabwe by providing alternative economic markets and, in some instances, military support. North Korea provided training to the military forces that were used to control the Matabeleland uprisings in the 1980s (De Waal 1990). Langa (2014b) argues that the construction in 2010 of a statue to commemorate the work of the late Vice President Joshua Nkomo made by a North Korean company instead of local sculptors has raised debates among the people of Matabeleland. President Mugabe commissioned the sculpture in December 2013 and it stands at the intersection of Joshua Nkomo Street and Eighth Avenue in Bulawayo. Many lobby groups have pointed out that a North Korean company had no moral standing to erect the sculpture because of the role their government played during the Gukurahundi massacres. The North Korean government has never shown remorse for its role in the massacres and this raises tensions among community members when such a tender is awarded to a company whose government is alleged to be responsible for the death and suffering of many people in the region (CCJPZ 1997, 
Langa 2014b).

Regional bodies, such as the African Union (AU) and the Southern African Development Community (SADC), have also played a role in resolving the conflict in Zimbabwe. According to Bell (2013a), the SADC Tribunal ruled in 2008 that the land invasions that occurred in Zimbabwe in 2000 and 2001 were unlawful and the government of Zimbabwe should compensate the farmers who incurred losses. The government of Zimbabwe has ignored the verdict and the ruling was made ineffective when the Tribunal was suspended in 2010. Zimbabwe's displaced commercial farmers took their case to the South African High Court which reinstated the ruling made by the SADC Tribunal and ordered the government of Zimbabwe to also pay R200 000 in legal fees. The High Court also ruled that the Cape Town property owned by the government of Zimbabwe should be auctioned to raise some funds for compensating the farmers. This has been the most notable ruling that the government of Zimbabwe has faced from a foreign non-state legal body (Bell 2013a).

Viljoen and Adebe (2014) point out that the AU, through the African Commission on Human Rights, potentially creates opportunities for victims to seek justice for human rights abuses committed by their governments. According to Bell (2013b), Gabriel Shumba became the first Zimbabwean to win a case against the government over human rights abuses handled by a regional body. The case of torture and abuse of Gabriel Shumba by the government in 2003 resurfaced in 2013 when the African Commission found the government guilty of inhumane actions and ordered it to pay compensation to Shumba for the suffering he incurred. Bell (2013b) suggests that the ruling of the African Commission might have created the opportunity for other victims of inhumane acts to challenge the government. However, the success of the African Commission in holding to account perpetrators of human rights violations is yet to be tested because the government of Zimbabwe is still challenging the ruling and this has delayed the case from being resolved (Bell 2013b).

\section{Matabeleland in the national context}

The Gukurahundi massacres occurred in the Midlands and Matabeleland provinces where the majority of the population is Ndebele, which the government seemingly associated with the ZIPRA dissidents and 
ZAPU (Eppel 2003). Eppel asserts that the stronghold of ZAPU in this region posed a geo-political threat to the ruling ZANU government, which might have forced the regime to employ excessive force to gain control of the region (Eppel 2009, Msindo 2012, Ndlovu and Dube 2013). Eppel (2008) and Sachikonye (2011a) suggest that the withdrawal of many Ndebeles from the 1987 Unity Accord, when Joshua Nkomo died in 1999, was inevitable. Their subsequent recruitment into the opposition party (particularly the MDC that was formed in 1999) has presented the Matabeleland region as an increasing threatening force to the ruling party (which is predominantly Shona) (Muzondidya and Ndlovu-Gatsheni 2007).

Several scholars have argued that the administrative divisions in Zimbabwe at independence fuelled the creation of political parties along ethnic lines (for example, ZAPU with an Ndebele majority and ZANU with a Shona majority), which made it difficult for government officials to create a well-integrated country (Msindo 2012, Ndlovu-Gatsheni 2009). The actions of the government during the Gukurahundi era and systematic unequal distribution of resources to the Matabeleland and Midlands provinces have resulted in deep resentments amongst the Ndebele in this region (Eppel and Raftopoulos 2008, Ndlovu-Gatsheni 2012). Ethnic divisions in Zimbabwe are a largely unacknowledged factor in the political discussions related to reconciliation to date, to the detriment, we argue, of any successful reconciliation process.

Muzondidya and Ndlovu-Gatsheni (2007) believe that the use of ethnicity to locate one's identity in Zimbabwe goes back to the colonial era. Ethnic divisions were institutionalised by the Smith regime that used it as a modus operandi to divide the country into administrative units, namely, Mashonaland, Manicaland, Masvingo, Midlands and Matabeleland. Mlambo (2013) argues that Zimbabwe has failed to build itself into a harmonious country with a common national identity because of the government propagated 'patriotic history'. He borrows the term patriotic history from Ranger (2010) who argues that there is a public history that is constantly propagated on state-controlled media, which assumes that the country has sustained its territorial integrity mainly because of the contribution of the spirit mediums of the Shona people during the colonial era. It is from this history that the legitimacy of the country and of the Mugabe regime derives.

Ndlovu-Gatsheni (2009) points out that the shaping of the history of Zimbabwe by the government around Shona patriotism might be 
inhibiting reconciliation among the Zimbabwean population. He asserts that the history of Zimbabwe cannot be simplified to one ethnic group because the country emerged from a complex mosaic of contending histories and memories. Ndlovu-Gatsheni (2009) and Ranger (2010) suggest, therefore, that the honouring of only the Shona culture in public celebrations about the history of the country, for example the spirit mediums Nehanda and Kaguvi, sidelines the contribution of other ethnic groups to the formulation of present day Zimbabwe. Mlambo (2013) argues that the patriotic history being promoted by the ruling government is a self-serving oversimplification of the country's history, which legitimises ZANU-PF hegemony in the country.

According to Gova and Ndlovu (2013) and Vambe (2012), most people in the Nkayi District suspect that the government has intentionally marginalised the people in the Matabeleland Province because of ethnic differences between the Shona people (who are the majority in government) and Ndebele people (who are a minority both in government and the country). Gova and Ndlovu (2013) add that the Nkayi District has remained impoverished and is characterised by high volumes of poverty, lack of infrastructure, water shortages and lack of adequate food supply, and that these conditions are not as highly prevalent in Shona populated areas.

The one notable attempt of the ruling government to be inclusive has been making both Shona and Ndebele official languages and mediums of teaching in schools, whilst other minority languages such as Nyanja, Shangani and Kalanga are officially recognised as mediums of communication mainly on radio stations (Muzondidya 2008, NdlovuGatsheni 2012). However, in the past three decades, the education level of pupils in Matabeleland has been affected by the shortage of qualified Ndebele speaking educators. Many students who cannot speak Shona have been forced to learn in a language different from their home language (Dube 2014). Various lobby groups and parents in Matabeleland have protested against the policy of instructing students in Shona, which infringes on the constitutional right of learners to learn in a medium of instruction they have proficiency in. Undoubtedly, the use of the Shona language by non-Ndebele speaking educators is affecting the level of literacy among non-Shona speaking students and Matabeleland remains the region with the poorest performance at grade seven, Ordinary level and Advanced level national examinations (Chronicle 2014, Dube 2014). 


\section{Reconciliation at the community level}

The central issue that emerged from the fieldwork in the Nkayi District are the deep resentments related to the unacknowledged Gukurahundi massacres and the perceived systematic marginalisation of Matabeleland in terms of development. Several scholars write about the ethnic divisions that characterise this region, and the apparent lack of interest on the part of the government to address underlying issues that trigger divisions in this region (Gova and Ndlovu 2013, Eppel 2006, Machakanja 2010, Sachikonye 2011b). Over the past three decades, many parts of the Nkayi District have witnessed sporadic episodes of political violence and the district as a whole has been subjected to deep-seated structural violence (Gova and Ndlovu 2013, Ncube 2001, NdlovuGatsheni 2008). This violence is believed by the community to have been orchestrated by the government in order to suppress any opposition to its leadership. The exposure of the local communities to violence has resulted in a number of its people migrating to neighbouring countries for refuge, with South Africa being the leading host.

The fieldwork revealed that most of the incidents of violence experienced in Nkayi were associated with the Gukurahundi era, with a few incidents reported to have occurred after 2000. Most of the incidents narrated by the participants identified government security agents as the perpetrators, particularly the Fifth Brigade and Police Intelligence (PISI). A few identified ZIPRA dissidents, and a few ZANU-PF youth militias as the perpetrators, in incidents that occurred in the post-2000 period. Acts of physical violence that the community has endured include rape, murder, beatings, destruction of property, displacements and humiliation. In addition to this direct violence, participants also described indirect violence through the domination of the Shona language. For example, the Shona language was used to suppress ZIPRA dissidents and civilians who were suspected of supporting dissidents. During Gukurahundi, if one could not speak Shona it was assumed one was a dissident or dissident-supporter and could face torture or death (Msindo 2012).

The CCJPZ (1997) report recorded that during Gukurahundi the Fifth Brigade soldiers often gathered people to a central point at gunpoint in the evenings, for example at a school. The people would be coerced to sing Shona songs that praised the ruling ZANU-PF govern- 
ment. This trend of using the Shona language and practices to coerce people to do particular actions seems to have continued even after the Gukurahundi massacres. One participant interviewed said: "The postMarch 2008 contested election period was a difficult time because people felt threatened by the government, especially the Border Gezi trained youths. They hosted overnight praises 'pungwe', singing Shona songs and people were being coerced to attend".

The Shona language has become a symbol of domination and its continued use reinforces the oppression of other ethnic groups, in this case Ndebele people. Msindo (2012) argues that conversing in Shona to an Ndebele person who is a victim of the Gukurahundi massacres, becomes an insult because it revives memories of a traumatic period. Eppel (2009) and Ndlovu-Gatsheni (2008) suggest that the massacres that occurred in Matabeleland could be described as an ethnic cleansing drive and evidence of an irrational reaction to the Ndebele minority which, they argue, may have an enduring impact on the relations between Ndebele speaking (particularly survivors of the massacres) and Shona speaking people.

During the fieldwork, the sense was, though, that in the communities in the Nkayi District, the resentments of Ndebele speaking people were against the government in particular, including the local government, rather than other Shona speaking people living in the community. Participants described intermarriages as relatively common, and peaceful co-existence between neighbours of differing ethnic groups, including Shona, Ndebele, Kalanga and Shangani among others. Respondents seemingly did not associate their general concerns regarding Shona speakers as a group with the individuals they interacted with on a daily basis. This would perhaps explain why the central concern of participants when it comes to reconciliation is having the government acknowledge Gukurahundi, rather than interpersonal healing between Shona and Ndebele people living in the same community. The dismissal of the violence perpetrated during this time, particularly in public speeches, has significantly undermined reconciliation in this area. Quite a number of participants referred directly to Mugabe's "moment of madness" speech and "let bygones be bygones". As one civil society leader in Bulawayo stated,

The government should not assume that the signing of the Unity Accord in 1987 and labelling the Gukurahundi era a 'moment of 
madness' has atoned for the atrocities that occurred. People's lives were disrupted for seven years, they therefore need to be consulted on the processes of reconciliation that will resolve the issues they have and not be constricted to get over their experiences briskly.

The concern that community members needed to be consulted with regard to reconciliation was shared by several of those interviewed. Public consultation has been identified as one of the central ways in which a national reconciliation process can gain legitimacy amongst local communities (Lederach 1997, Schaap 2008). Without this, it becomes an imposed process which is unlikely to be sustained in local communities where members of those communities do not have a sense of ownership over the process. Along with acknowledgement and public consultation, participants expressed wanting to know what happened and why. As one participant said,

I still want to understand why the dissidents killed my father in front of the whole family. I really need to know what they were thinking when they forced me to cut him into pieces. These questions remain in my mind and I do not know if I will ever get the chance to ask for the answers (54-year-old man).

Significantly, most of the participants did not favour criminal prosecutions. Reasons for this included the danger that prosecutions would focus on determining the wrongful acts of a perpetrator forensically, rather than hearing the testimonies of the victim. In addition, criminal court proceedings are usually long and lawyers often get entangled in following court procedures rather than soliciting the truth that is needed for justice to be served. One civil society leader said, "It must be put on record that perpetrators of violence went on trial even if they end up being pardoned, unlike granting blanket amnesty without getting people to account for their inhuman actions". This suggests that acknowledgment is more important than the prosecution itself.

Reburials also seemed to be an important concern for participants. As one interviewee indicated, conducting proper burials for victims of Gukurahundi is a practical way the government can offer acknowledgement to survivors of violence in the Matabeleland region. She said,

There are many unidentified graves in Matabeleland, the least that the government can do to help survivors ease off the pain they have been holding for the past 30 years is exhuming mass graves, identi- 
fying the deceased, and giving bereaved families the opportunity to mourn and rebury their beloved ones in a proper manner.

This view was shared by many of those interviewed. Two of the community members in Nkayi indicated that they were aware of a mass grave where their relatives have been lying for the past 30 years but they have not been able to rebury them because government authorities have rejected their request to conduct reburials. Eppel (2006) describes how during the Gukurahundi massacres many of the people that died were buried in mass graves because the communities were too unstable for people to conduct proper burials. She argues that many of the mass graves have not been exhumed and this has left communities without possession of the remains of their loved ones. Msindo (2012) points out that in Zimbabwean African culture, proper burial of the remains of a deceased party is a crucial element of the moral fabric of communities. He indicates that giving proper burial to deceased parties is a sign of respect to both the living and spiritual worlds. Eppel (2006) adds that to the living world, burial symbolises respect for human dignity. To the spiritual world, burial is a passage rite that allows the spirit of the deceased to reconnect with the ancestral family. The failure of bereaved families to bury victims of Gukurahundi and other episodes of violence in Zimbabwe remains a contentious issue because of the moral obligation of communities to respect both the living and spiritual worlds.

In addition to this, participants placed a high value on the development of the Matabeleland areas. In almost all of the discussions with community members and civil society leaders, lengthy accounts of the underdevelopment of Matabeleland were given. One of the academic experts stated:

The benchmark of reconciliation lies in the quality of life people have. If the structures and systems of the community remain oppressive and unresponsive to the socio-economic needs of the people then it remains a challenge for people to attain reconciliation. Community development ought to happen through the people, by the people and for the people.

Reconciliation, for the research participants, relies on the efforts of the government to improve the standards of living for all citizens. Ndlovu and Dube (2013) support this view. They argue that if issues of under- 
development in the Matabeleland region (including the Nkayi District) are not addressed, the community remains vulnerable to structural violence. Improved standards of living for Matabeleland people imply access to water, education, health care and industrialisation, among others (NANGO 2012).

\section{Conclusion}

Although it is always difficult to know when the right time to deal with the past is, ignoring the past has the danger of the violence being perpetuated, particularly during election periods (Muzondidya and NdlovuGatsheni 2007). Violence in Zimbabwe over the past three decades has dehumanised the victims, perpetrators, families, communities and even outsiders who have heard narrations of the incidents (Mlambo 2013, Ndlovu-Gatsheni 2009, Sachikonye 2011a). Yet, very little has been done to deal with this at the local community level. From the discussion in this article it is evident that what the communities in Matabeleland want is to have Gukurahundi acknowledged, to know what happened, and to rebury their dead in a more dignified manner. Those we spoke to did not seem to prioritise criminal prosecutions but they were particularly offended by the public dismissal of the horror of the past. Participants stressed the importance of consultation with them. Of central importance to those we spoke to is the development of the Matabeleland region. This seems to be an important starting point for developing national reconciliation initiatives. Rather than starting from the top down, a human security approach would take seriously what community members in Matabeleland are saying. What community members in the Nkayi District are asking for resonates with what communities across the continent seem to want from a reconciliation process, but is rarely what a nationally initiated reconciliation process seems to offer. A human security approach to reconciliation would take into account the needs and issues of community members as the starting point for national reconciliation projects.

\section{Endnotes}

1. Ruth Murambadoro is a doctoral candidate in the Department of Political Sciences at the University of Pretoria. Cori Wielenga is a postdoctoral fellow in the Department of Political Sciences at the University of Pretoria. 
2. Fieldwork was undertaken by the first author for her Master's dissertation on reconciliation in Zimbabwe titled, "The politicization of reconciliation in Zimbabwe: a case study of the Nkayi District". The second author, as supervisor of the Master's, participated in the fieldwork for a brief period.

3. Matabeleland (North and South) and Midlands Provinces cover the west and south-west parts of the country and their main ethnic group is the Ndebele people. Mashonaland (West, East and Central) covers the northern part of the country that is largely populated by the Zezuru, a dialect of Shona. Masvingo Province is located in the southeast and is inhabited by Karanga people who speak another dialect of the Shona. Manicaland is situated in the eastern part of Zimbabwe populated by the Manyika people, who also speak a dialect of the Shona (Census 2012).

4. Operation Murambatsvina refers to the militarised uprooting of informal settlements in the urban areas across the country, which resulted in the displacement of over 600000 people and a direct loss of sources of income for 1.7 million people (Sokwanele 2005).

5. CSOs are a voluntary body of actors that involve population groups who engage in dialogue, deliberation, confrontation and negotiation with each other and with the government and business (Salamon 2010: 168).

\section{Bibliography}

Bell, A (2013), Victory for white farmers in land case. (Available at http:// nehandaradio.com/2013/09/18/victory-for-white-farmers-in-land-case/, last accessed 21 February 2014.)

Bell, A (2013), "Zim government found responsible for torture in landmark ruling". (Available at: http://allafrica.com/stories/201303260173.html, last accessed 22 May 2013.)

Brounéus, K (2003), Reconciliation-Theory and Practice for Development Cooperation. A Report for the Swedish International Development Cooperation Agency.

Brounéus, K (2009), Reconciliation and development. Berlin Heidelberg: Springer, pp 203-216.

Catholic Commission for Justice, Peace in Zimbabwe, and Legal Resources Foundation Zimbabwe (1997), Breaking the Silence, Building True Peace: A Report on the Disturbances in Matabeleland and the Midlands, 1980 to 1988. Catholic Commission for Justice and Peace in Zimbabwe.

Census (2012), Zimbabwe 2012 Census. Zimbabwe Government Publications.

Chronicle (2014), "Shona teachers shouldn't teach in Bulawayo: education minster agrees with Bulawayo residents". (Available at: http://www.myzimbabwe. co.zw/news/412-shona-teachers-shouldn-t-teach-in-bulawayo-education- 
minister-agrees-with-byo-residents.html, last accessed 1 June 2014.)

De Waal, V (1990), The politics of Reconciliation: Zimbabwe's first decade. London: Hurst \& Company.

Dube, V (2014), "Uproar over non-Ndebele speaking teachers". (Available at: http:// www.zimbabwesituation.com/news/uproar-non-ndebele-speakers/, last accessed 29 June 2014.)

Du Plessis, M and J Ford (2009), "Transitional Justice: A Future Truth Commission for Zimbabwe?", International and Comparative Law Quarterly, Vol 58, No 1, pp 73-117.

Eppel, S (2003), "A brief history of violations of human rights in Zimbabwe since 1965 to present". Paper for the International Centre for Transitional Justice, New York.

Eppel, S (2008), "Matabeleland: Its struggle for national legitimacy and the relevance of this in the 2008 election", Perspectives, Vol 2, No 8, pp 1-7.

Eppel, S (2009), "A tale of 3 dinner plates: Truth and challenges of human rights research in Zimbabwe", Journal of Southern African Studies, Vol 35, No 4, pp 967-976.

Eppel, S and B Raftopoulos (2008), Political Crisis, Mediation and the Prospects for Transitional Justice in Zimbabwe. Cape Town: IDASA.

Gova, M and C Ndlovu (2013), "Gukurahundi healing integrates Nkayi". (Available at: http://www.thezimbabwean.co/politics/64512/gukurahundi-healing-integrates -nkayi.html, last accessed 5 September 2013.)

Hapanyengwi-Chemhuru, O (2013), "Reconciliation, conciliation, integration and national healing: Possibilities and Challenges in Zimbabwe", African Journal on Conflict Resolution, Vol 13, No 1, pp 79-99.

International Crisis Group (2008), Ending Zimbabwe's Nightmare: A Possible Way Forward. (Available at: http://www.crisisgroup.org/en/regions/africa/southernafrica/zimbabwe/B056-ending-zimbabwes-nightmare-a-possible-way-forward. aspx, last accessed 16 May 2013.)

Langa, V (2014), "Tempers flare in Parliament". (Available at: https://www.newsday. co.zw/2014/03/26/tempers-flare-parliament/, last accessed 26 March 2014.)

Langa, V (2014), "Mliswa demands probe on Joshua Nkomo statue construction". (Available at: https://www.newsday.co.zw/2014/03/06/mliswa-demands-probejoshua-nkomo-statue-construction/, last accessed 9 August 2014.)

Lederach, J P (1997), Building Peace: sustainable reconciliation in divided societies, United States Institute of Peace Press.

Machakanja, P (2010), National healing and Reconciliation in Zimbabwe: Challenges and opportunities, Institute for Justice and Reconciliation.

Machinga, M M (2012), Pastoral care in post-violence situation: Tending to the visible and invisible wounds of survivors in three communities in Manicaland 
Province of Zimbabwe, Doctoral Dissertation, Claremont School of Theology. Mashingaidze, T M (2010), "Zimbabwe's illusive National Healing and Reconciliation processes: From Independence to the Inclusive Government 19802009", Conflict Trends, Issue 1, pp 19-27.

Mbire, M (2011), Seeking reconciliation and national healing in Zimbabwe: case of the organ on national healing, reconciliation and integration (ONHRI), Erasmus University.

Mlambo, A S (2013), "Becoming Zimbabwe or Becoming Zimbabwean: Identity, Nationalism and State-building", Africa Spectrum, Vol 48, No 1, pp 49-70.

Msindo, E (2012), Ethnicity in Zimbabwe: transformations in Kalanga and Ndebele societies, 1860-1990. Rochester: University of Rochester Press.

Muzondidya, J (2008), "From buoyancy to crisis, 1980-1997", in Raftopoulos, B and A, S Mlambo (2008) (eds), Becoming Zimbabwe: A history from the precolonial period to 2008. Auckland Park: Jacana Media.

Muzondidya, J, and S Ndlovu-Gatsheni (2007), "Echoing silences: ethnicity in postcolonial Zimbabwe, 1980-2007", African Journal on Conflict Resolution, Vol 7, No 2, pp 275-297.

National Association of Non-Governmental Organisations (2012), Compendium of civil society submissions at the EU delegation and civil society dialogue, NANGO Western region.

Ncube, C (2001), "Zimbabwe: Political violence erupts in Matabeleland". (Available at http://allafrica.com/stories/200106210072.html, last accessed 30 September 2013.)

Ndlovu, I and B Dube (2013), "Response to Maurice T. Vambe's 'Zimbabwe genocide: voices and perceptions from ordinary people in Matabeleland and the Midlands provinces, 30 years on", African Identities, Vol 11, No 4, pp 353-366.

Ndlovu-Gatsheni, S J (2008), "Patriots, Puppets, Dissidents and the Politics of Inclusion and Exclusion in contemporary Zimbabwe", Eastern Africa Social Science Research Review, Vol 24, No 1, pp 81-108.

Ndlovu-Gatsheni, S J (2009), "Nation building in Zimbabwe and the challenges of Ndebele particularism", African Journal on Conflict Resolution, Vol 8, No 3, pp 27-55.

Ndlovu-Gatsheni, S J (2012), "The death of the subject with a capital 'S' and the perils of belonging: A study of the construction of ethnocracy in Zimbabwe", Critical Arts: South-North Cultural \& Media Studies, Vol 26, No 4, pp 525-546.

Ndlovu-Gatsheni, S J (2013), "Towards decoloniality in Zimbabwe". (Available at: http://www.newzimbabwe.com/opinion-12424-Towards+\%E2\%80\% 98decoloniality\%E2\%80\%99+in+Zimbabwe/opinion.aspx, last accessed 23 July 2014.)

Ndou, P (2012), "Release the Chihambakwe \& Dumbutshena reports". (Available at http://bulawayo24.com/index-id-news-sc-local-byo-15284.html, last accessed 
23 July 2014.)

Nordquist, K (2007), "Reconciliation as a Political Concept: Some Observations and Remarks", Perspectives on Peace and Conflict Research, 197.

Raftopoulos, B and T Savage (2004), Zimbabwe: Injustice and political reconciliation. Institute for Justice and Reconciliation. Cape Town: Weaver Press.

Ranger, T (2010), "Constructions of Zimbabwe", Journal of African Studies, Vol 36, No 2, pp 505-510.

Sachikonye, L (2011), Curse of political violence: Time to break the cycle of terror. OSISA.

Sachikonye, $L$ (2011), When a state turns on its citizens: institutionalised violence and political culture. Auckland Park: Jacana Media.

Salamon, L M (2010), "Putting the civil society sector on the economic map of the world", Annals of Public \& Cooperative Economics, Vol 81, No 2, pp 67-210.

Schaap, A (2008), Reconciliation as Ideology and Politics, Constellations, Vol 15, No 2, pp 1-16.

Sibanda, T (2011), "Unity day holiday no longer relevant in Zimbabwe", SW Radio Africa, (Available at: http://allafrica.com/stories/201201030151.html, last accessed 11 August 2013.)

Sokwanele, (2005), Operation Murambatsvina: An overview Summary. (Available at: http://www.sokwanele.com/articles/sokwanele/opmuramboverview18june 2005.html, last accessed 16 May 2013.)

Sokwanele, (2013), National Peace and Reconciliation Commission. (Available at: http://www.sokwanele.com/zimbabweconstitution/sections/477, last accessed 16 May 2013.)

Sriram, C L (2009), "Introduction: Transitional justice and peacebuilding", in Sriram, $C L$ and S Pillay (eds), Peace Versus Justice? The Dilemma of Transitional Justice in Africa. Scotsville: University of KwaZulu-Natal Press.

Taylor, I (2007), "What Fit for the Liberal Peace in Africa?", Global Society, Vol 21, No 4, pp 553-566.

Thomson, $\mathrm{A}$, and $\mathrm{N}$ Jozdowska (2012), "Bringing in the grassroots: transitional justice in Zimbabwe", Conflict, Security \& Development, Vol 12, No 1, pp 75102.

Vambe, M T (2012), "Zimbabwe genocide: Voices and perceptions from ordinary people in Matabeleland and the Midlands provinces, 30 years on", African Identities, Vol 10, No 3, pp 281-300.

Viljoen, F and A K Adebe (2014), "Amicus curiae participation before regional human rights bodies in Africa", Journal of African Law, Vol 5, No 1, pp 22-44.

Zambara, W (2012), "Zimbabwe: No justice, no reconciliation", SA Reconciliation Barometer. (Available at: http://reconciliationbarometer.org/newsletter/volume -ten-2012/zimbabwe-no-justice-no-reconciliation/, last accessed 9 August 
2014.)

Zhira, M (2008), "Uncovering the Reality of State Violence in Western Zimbabwe, 1982-1987", Past Imperfect, Vol 10, pp 59-78.

Zimbabwe Human Rights NGO Foru, (2013), The Transitional Justice Second International Conference Report, (Available at: http://www.hrforumzim.org/wpcontent/uploads/2014/07/ICTJ-II-Conference-Report.pdf, last accessed 9 August 2014.) 